\title{
Replication in situ and DNA Encapsulation Following Induction of an Excision-defective Lysogen of Salmonella Bacteriophage P22
}

\author{
Steven Weaver $\dagger$ and Myron Levine \\ Department of Human Genetics, The University of Michigan \\ Ann Arbor, Mich. 48109, U.S.A.
}

(Received 4 April 1977, and in revised form 9 September 1977)

\begin{abstract}
The induction of an excision-defective bacteriophage P22 lysogen results in the production of particles which carry a DNA molecule of normal length within a normal capsid, but which are nonetheless defective. The DNA content of these particles was characterized physically by a restriction enzyme analysis, and genetically by two marker rescue techniques. The particles carry DNA corresponding to one side of the prophage map as well as additional DNA, apparently derived from the host chromosome to one side of the prophage insertion site. Normally, mature P22 DNA molecules are derived from a concatemer by sequential cleavage of adjacent headful lengths, beginning at a genetically unique site, the encapsulation origin (Tye et al., 1974). The defective particles appear to contain DNA matured by the same sequential mechanisms, operating on the integrated prophage and neighboring bacterial chromosome, rather than on the normal concatemeric substrate. Both the initiation and directional specificities of normal maturation are maintained during the maturation of defective particle DNA. Sequential cleavage begins within the prophage at the encapsulation origin, a site near gene 3 , and proceeds into the host chromosome on the proC side of the prophage. The initiation specificity of DNA encapsulation seems to reside in the morphogenetic machinery, rather than in the mechanism of DNA replication. Replication of an induced excision-defective prophage takes place in situ on the host chromosome, apparently without disruption of the linear integrity of the prophage. Further, the entire prophage, as well as adjacent baoterial DNA, is replicated, even though only a portion of this DNA is destined to be encapsulated.
\end{abstract}

\section{Introduction}

The excision as well as the integration of temperate bacteriophage P22 requires the action of the product of the phage int gene (Smith \& Levine, 1967; Smith, 1968). A similar dual requirement has been observed in the case of phage $\lambda$ (Gottesman \& Yarmolinsky, 1968). Most P22 int ${ }^{-}$mutants, which were selected for the inability to establish stable lysogeny, are defective for excision as well. Because the int gene product can act in trans, and because its activity is not required for the maintenance of the prophage state (Smith \& Levine, 1967), stable int $^{-}$lysogens can be constructed by complementation techniques. Induction of P22 int- lysogens, either by ultraviolet light or by thermal inactivation of a temperature-sensitive repressor, brings about cell death and lysis at the normal time. From each induced cell 100 to 200

† Present address: Department of Bacteriology and Immunology, The University of North ( arolina, Chapel Hill, N.C. 27514, U.S.A. 
phage particles are released. However, the vast majority of these particles are defective; only one in $10^{3}$ to $10^{4}$ is able to form a plaque (Smith, 1968).

Smith (1968) showed that these defective particles carry a DNA molecule of normal length within an apparently normal capsid. The particles exhibit an increased buoyant density in $\mathrm{CsCl}$, an effect that can be accounted for if the particles contain a substantial proportion of bacterial DNA. This inference was confirmed by hybridization experiments, which suggested that half to two-thirds of the DNA contained by a population of defective particles was of bacterial origin. Genetic evidence for the encapsulation of bacterial DNA was provided by the demonstration that the defective particles could transduce certain bacterial markers with unusually high frequencies. This enhancement was peculiar in that increased frequencies of transduction were observed only in the case of the proC and pur $\mathrm{E}$ markers, which map close to and on the right side of the prophage attachment site (see Fig. 1). Significantly, no preferential transduction was observed in the case of the pro $\mathrm{A}$ and proB loci; these genes lie on the opposite side of the attachment site from proC (Fig. 1). Marker rescue experiments (Smith, 1968) revealed an asymmetry in the encapsulation of phage DNA sequences as well. Phage markers within the right-hand side of the prophage map, the side adjacent to the proC region of the host chromosome, could be recovered with high frequency, whereas markers in the left side of the prophage map could be rescued only at very low levels.

Smith proposed that an induced excision-defective prophage carried out its own replication in situ, while still integrated within the host chromosome, and that this replication was not limited to the prophage DNA but proceeded past the attachment sites into the bacterial chromosome. He suggested that there might be a polarity to the replication process, that "rightward" prophage and adjacent bacterial DNA was preferentially replicated. Subsequently, in the process of morphogenesis, the replicated DNA would be cleaved at random into molecules of headful size and packaged within structurally normal capsids.

Recent work by Tye et al. (1974) indicates that encapsulation of P22 DNA is not random with respect to sequence. Normal P22 DNA is terminally redundant and circularly permuted (Rhoades et al., 1968). By partial denaturation mapping and heteroduplex analysis, Tye et al. (1974) demonstrated that the circular permutation is limited; that is, the ends of normal P22 DNA molecules fall within a restricted sector, about $20 \%$ of the physical map. They also examined DNA from several deletion-substitution derivatives of P22, which were shown to have a slightly decreased phage genome size, and observed a relation between the size of the terminal redundancy and the distribution of molecular ends on the physical map: DNA molecules carried by the deletion mutants possess longer than normal terminal redundancies, and the ends of such mutants are spread more widely over the physical map. The greater the terminal redundancy, the broader is the distribution of the molecular ends.

This relationship can be accounted for (Tye et al., 1974) by an extension of the model for phage maturation originally proposed by Streisinger et al. (1967). The 'Tye model contends that phage P22 DNA molecules of headful length are derived sequentially from a multimeric precursor, or concatemer (Botstein \& Levine, 1968), and that a series of consecutive cleavages begins at a genetically unique site, the "encapsulation origin", and proceeds in a unique direction. After the encapsulation origin has been recognized, maturation cutting has no sequence specificity; headfuls 
of DNA are cut from the concatemer solely on the basis of physical length. Restriction endonuclease analysis of DNA from normal P22 and of DNA from P22 derivatives carrying deletions or substitutions has confirmed and extended this model (Jackson et al, $1978 a, b)$.

The properties of the defective particles released on induction of excision-defective lysogens can be explained within the framework of the sequential encapsulation model. Maturation cutting and packaging of DNA into phage particles would begin within the integrated prophage at the normal origin of encapsulation, and would proceed in a unique direction into the host chromosome, to one side of the prophage. The resulting population of particles would contain both phage and host DNA. The first headful of DNA matured in a series of consecutive cleavages would carry an incomplete set of phage genes, those lying to one side of the encapsulation origin, as well as some bacterial DNA. Subsequent headfuls would consist exclusively of bacterial DNA. All such particles would be non-infectious, since none would carry a complete phage genome.

In this paper we present evidence to support this idea. Digestion of DNA obtained from defective particles with the EcoRI restriction endonuclease yields restriction fragments corresponding only to one side of the prophage. Genetic analysis of the defective particles demonstrates that they contain a limited number of phage genes, all of which lie to one side of a point near the center of the prophage map. Finally, we show that induction of an excision-defective lysogen leads to replication of the entire prophage in situ, even though only a portion of it is destined to be encapsulated. This result indicates that the unusual DNA content of defective particles reflects the specificities of normal P22 DNA maturation, rather than the manner of replication of prophage DNA.

\section{Materials and Methods}

(a) Media, solutions, reagents and enzymes

LB broth (Levine, 1957), M9CAA (Smith \& Levine, 1964), tryptone agar for plates (Bronson \& Levine, 1971), phosphate buffered saline (PBS) and soft agar for overlays (Levine, 1957) have been described. TES buffer is $10 \mathrm{~mm}$-Tris. $\mathrm{HCl}$ (pH 8.1), $1 \mathrm{~mm}$-EDTA, $10 \mathrm{~mm}-\mathrm{NaCl}$. $\mathrm{E}$ buffer is $40 \mathrm{mM}$-Tris-acetate (pH 8.0), $1 \mathrm{~mm}$-EDTA, 5 mM-sodium acetate. Lysis mixture contains $0.5 \mathrm{M}$-Tris. $\mathrm{HCl}(\mathrm{pH} \mathrm{8.0),} \mathrm{0.5} \mathrm{M-EDTA,} 0.05 \mathrm{M}-\mathrm{NaCN}, 0.025 \mathrm{M}$ sodium iodoacetate, $4 \mathrm{mg}$ lysozyme/ml. The lysozyme and iodoacetate were added just before use. Tetracycline, lysozyme (egg white, $3 \times$ crystallized) and Pronase (free of nucleases) were purchased from Calbiochem. Pronase was dissolved as a $10 \mathrm{~mm} / \mathrm{ml}$ solution in $10 \mathrm{~mm}$-Tris. $\mathrm{HCl}$ (pH 8.1) and autodigested before use as described by Young \& Sinsheimer (1967). Scintillation fluid was as described by Smith (1968). Agarose was purchased from SeaKem.

\section{(b) Phage and bacteria}

All bacterial strains derive from Salmonella typhimurium LT-2. The prototrophic strain 18 was described by Levine (1957). The amber supressor strain 325 is the same as DB74 (Botstein \& Matz, 1970). A number of tetracycline-resistant prophage deletion lysogens isolated by Chan \& Botstein (1972) were used in this work. They are listed, and their genetic content diagrammed, in Fig. 1. These lysogens were maintained on solid media containing tetracycline at $25 \mu \mathrm{g} / \mathrm{ml}$, and were grown as indicator cultures in LB broth containing the same concentration of the drug. The prophage in these $t^{\mathrm{R}} \boldsymbol{t}^{\mathrm{R}}$ strains is very unstable. To confirm the presence of the prophage, each single colony isolate used was checked for immunity to P22 ant ${ }^{-}$phage (Levine et al., 1975; Botstein et al., 1975).

Phage carrying combinations of the following mutations were constructed by standard recombinational techniques as needed. Smith \& Levine (1967) described the P22 mutations int3 and int 11 . The clear mutant $22-5$ was described by Levine \& Curtiss (1961). The 


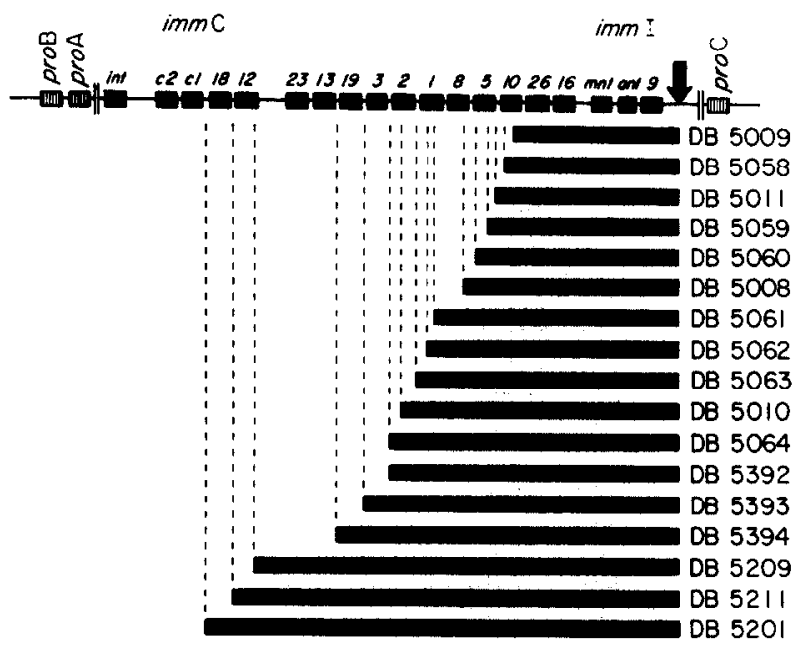

FIG. 1. Genetic map of P22 prophage. The bars describe the extent of the internal deletion for each of the prophage deletion lysogens used in this paper. The arrow on the genetic map indicates the position at which the determinant for tetracycline resistance is inserted in these lysogens.

mutations $c 2$-ts29 (Levine \& Smith, 1964), and $c 2$-ts30 (Gough, 1970), confer temperature inducibility to P22 prophage. The gene 19 mutation amN11l causes delayed lysis (Botstein et al., 1972). The ts 1.1 mutation lies in gene 1 , which codes for a minor component of the phage head (Botstein et $u l ., 1973$ ). Other temperature-sensitive and amber phage mutants are from the collections of M. Levine and D. Botstein.

Lysogens carrying int $t^{-}$prophage were constructed by complementation with $\mathbf{c 2 - 5}$ phago as describod by Smith (1968). Four such lysogens were used in this work: strain 1023 is 18 (P22int 11 c2-ts30); strain 1028 is 18 (P22int 3 c2-ts29); strain 1032 is 18 (P22 int3 c2-ts29 19-amN111); strain 1033 is 18 (P22int3 c2-ts29 19-amN111 1-ts1.1).

\section{(c) Preparation of defective particles}

Defective particles were produced by induction of strain 1023 or 1028 . Cultures were grown in $\mathrm{LB}$ broth at $25^{\circ} \mathrm{C}$ to a concentration of $2 \times 10^{8}$ cells $/ \mathrm{ml}$ and induced by transfer to $41^{\circ} \mathrm{C}$. Spontaneous lysis occured 60 to $90 \mathrm{~min}$ later. Particles were purified by differential centrifugation and banding in a discontinuous $\mathrm{CsCl}$ gradient as described by Botstein (1968), followed by dialysis against PBS. The particle concentration was determined optically using the conversion factor given by Smith $(1968): 1.8 \times 10^{-12}$ O.D. $260 \mathrm{~nm} /$ particle. Phage particles produced by thermal induction of P22 lysogens are characteristically deficient in tail protein, and are unable to adsorb to cells. This problem can be overcome by incubation in vitro with purified tail protein (Israel, 1967; Israel et al., 1967). Accordingly, defective particle preparations to be used for infections were treated with "tails" prepared according to Hoffman \& Levine (1975).

\section{(d) Radioactive phage and defective particles}

Defective particles labeled with $\left[{ }^{3} \mathrm{H}\right]$ thymidine were prepared by induction as described above, except that M9CAA was used as the growth medium. At the time of induction, deoxyadenosine $(250 \mu \mathrm{g} / \mathrm{ml})$ and $\left[{ }^{3} \mathrm{H}\right]$ thymidine $(10 \mu \mathrm{Ci} / \mathrm{ml} ; 60 \mathrm{Ci} / \mathrm{mmol})$ were added. Normal P22 phage labeled with ${ }^{32} \mathrm{P}$ were prepared by infection of strain 18 cells with $c 2-5$ phage as described by Botstein (1968). The particles were purified on discontinuous $\mathrm{CsCl}$ gradients and dialyzed into PBS as described above.

(e) Purification of phage or defective particle $D N A$

Reagent grade phenol was redistilled and stored as a solid in the dark at $-20^{\circ} \mathrm{C}$. Just before use the crystals were liquefied by warming and by the addition of an equal volume 
of $0.5 \mathrm{M}$-Tris. $\mathrm{HCl}(\mathrm{pH} 8$ ), then cooled and extracted 3 times at room temperature with TES buffer. DNA was purified from phage or defective particles by 3 extractions with prepared phenol carried out by gentle shaking at room temperature, followed by extensive dialysis against TES buffer.

\section{(f) Marker rescue experiments}

A slight modification of the method of Smith (1968) was used. A portion $(0.1 \mathrm{ml})$ of strain 18 cells in LB at a concentration of $1 \times 10^{8} / \mathrm{ml}$ was added to $10^{6}$ defective particles and $5 \times 10^{7}$ amber phage in a volume of $0.2 \mathrm{ml}$ at room temperature. After adsorption for $10 \mathrm{~min}, 1 \mathrm{ml}$ of $\mathrm{LB}$ was added, and $0.1 \mathrm{ml}$ of the diluted culture plated at $25^{\circ} \mathrm{C}$ on strain 18 indicator. Control infections, in which either the defective particles or the amber phage were ornitted, were performed in parallel.

\section{(g) Preparation of labeled intracellular DNA}

Cultures of strain 1032 or 1033 were grown at $25^{\circ} \mathrm{C}$ in M9CAA to $2 \times 10^{8}$ cells $/ \mathrm{ml}$, then induced by heating to $41^{\circ} \mathrm{C}$. After $15 \mathrm{~min}$, deoxyadenosine $(250 \mu \mathrm{g} / \mathrm{ml})$ and $\left[{ }^{3} \mathrm{H}\right]$ thymidine $(100 \mu \mathrm{Ci} / \mathrm{ml} ; 60 \mathrm{Ci} / \mathrm{mmol})$ were added. After $30 \mathrm{~min}$ of labeling, the cultures were lysed by a modification of the method of Enquist \& Skalka (1973): $4 \mathrm{ml}$ of culture were mixed with $1 \mathrm{ml}$ of lysis mixture. Then $0.5 \mathrm{ml}$ of autodigested Pronase $(10 \mathrm{mg} / \mathrm{ml})$ and $0.1 \mathrm{ml}$ of a $10 \%$ solution of sodium dodecyl sarcosinate were added. Lysis was achieved by heating at $65^{\circ} \mathrm{C}$ for $5 \mathrm{~min}$. The lysates were digested for $1 \mathrm{~h}$ at $37^{\circ} \mathrm{C}$, heated to $65^{\circ} \mathrm{C}$ for an additional $5 \mathrm{~min}$ and cooled to room temperature. The lysates were extracted 3 times with equal volumes of phenol prepared as described above and dialyzed against TES buffer in the cold. Two days later these preparations were digested with EcoRI and analyzed by electrophoresis.

\section{(h) Digestion of DNA with EcoRI nuclease}

Preparations of EcoRI restriction endonuclease were obtained from $\mathrm{H}$. Miller or from Miles Laboratories (batch 4). The latter enzyme was diluted 1:10 in 0.01 M-KPO ${ }_{4}(\mathrm{pH}$ $7 \cdot 0) .7 \mathrm{~mm}-2$-mercaptoethanol, $1 \mathrm{~mm}$-EDTA, $0 \cdot 2 \mathrm{M}-\mathrm{NaCl}, 0 \cdot 2 \% \mathrm{NP} 40$ before use. Reactions were performed in TES buffer which had been supplemented with $\mathrm{MgCl}_{2}$ to $10 \mathrm{mM}$. 'To a volume of 25 to $100 \mu$ of DNA solution was added 1 to $2 \mu \mathrm{l}$ of EcoRI enzyme. (This amount of enzyme was determined empirically to be a 2-fold excess over that necessary to digest 2 to $3 \mu \mathrm{g}$ of P22 DNA to completion under our conditions.) The DNA concentrations did not exceed $40 \mu \mathrm{g} / \mathrm{ml}$. The mixtures were incubated at $37^{\circ} \mathrm{C}$ for $30 \mathrm{~min}$, heated to $70^{\circ} \mathrm{C}$ : for $5 \mathrm{~min}$, and then quickly cooled in ice. Before layering on gels, $0.1 \mathrm{vol}$. of a solution of $80 \%$ sucrose in $\mathrm{E}$ buffer containing $0.5 \%$ bromophenol blue was added: $25 \mu \mathrm{l}$ of this mixture was applied to each gel.

\section{(i) Agarose gel electrophoresis}

Electrophoresis was performed in $16 \mathrm{~cm} \times 0.6 \mathrm{~cm}$ (i.d.) tubes. Before use, the tubes were dipped in a solution of Photo-Flo (Eastman Kodak; diluted 1:200). drained and baked at $70^{\circ} \mathrm{C}$ overnight. Rubber plugs $(0.6 \mathrm{~cm}$ diam.) coated with a thin layer of silicone grease were inserted into each tube. A solution of $0.7 \%$ agarose in $\mathbf{E}$ buffer was prepared by autoclaving and stored molten at $50^{\circ} \mathrm{C}$. This was poured into the gel tubes above the rubber plugs to a depth of $15 \mathrm{~cm}$. The plugs were then carefully removed, without twisting. The use of rubber plugs has two advantages: it permits the length of the gel to be determined at the time of casting, and provides an even surface on which the sample can be layered. During electrophoresis, the gels were retained within the tubes by nylon netting held over the bottom of the tube by a collar cut from vinyl tubing. The buffer chambers contained $\mathbf{E}$ buffer. Samples were run into the top of the gel by electrophoresis for $2 \mathrm{~min}$ at $100 \mathrm{~V}$. Gels to be stained with ethidium bromide were run at $25 \mathrm{~V}$. Electrophoresis at $60 \mathrm{~V}$ was used for gels to be sliced and assayed by scintillation counting.

Staining by ethidium bromide fluorescence was performed according to Helling et al. (1974). Photographs were taken with Polaroid type 52 or type $55 \mathrm{P} / \mathrm{N}$ film using an orange filter (Tiffen no. 15).

Slicing of gels containing radioactive DNA was done with an array of razor blades 
separated by metal shims to give approximately 130 or 140 fractions from a 15 -cm gel. A l-cm strip of glass-fiber paper (Gelman type E) was placed on the blades and sliced by rolling with a rubber stopper so that the slices were retained between the blades by friction, flush with the cutting edges. The gels were then extruded from the electrophoresis tubes directly onto the blades by the use of a metal rod about $5 \mathrm{~mm}$ in diameter which was clamped just above, and in line with, the blade array, so that the end of the rod was just above the end blade. The tube containing the gel was positioned over the blades and pushed carefully onto the rod. The rod extrudes the gel directly onto the blades without distortion. The gels were carefully dried, while resting on the blades, under infrared lamps until almost dry but not crisp. A second strip of glass-fiber paper was then placed over the first, to enclose the nearly dry gel in a sandwich, which was then sliced with the rubber stopper. It is important that the gels be not completely dry, as slicing them becomes difficult. The glass-fiber paper serves two functions. First, the paper sandwich simplifies retrieval of the slices of dried gel. Secondly, the bottom strip serves as a wick, drawing moisture from the gel and hastening the drying process. Considerable DNA also diffuses into the paper, particularly molecules of small molecular weight. The slicing of the bottom paper strip beforehand prevents spreading of the bands by diffusion. Also, preliminary slicing of the bottom strip exposes the blades, which bite slightly into the gel. This prevents curling and shortening of the gel as it dries.

Both the chips of dried gel and their paper sandwiches were transferred into l-dram glass scintillation vials: $0.1 \mathrm{ml}$ of water and then $0.5 \mathrm{ml}$ of NCS solubilizer (Amersham) was added. The vials were capped and shaken for 15 to $18 \mathrm{~h}$ at $50^{\circ} \mathrm{C}$. After the samples cooled to room temperature, $3.5 \mathrm{ml}$ of scintillation fluid supplemented with $0.1 \%$ glacial acetic acid was added. The samples were then kept for several hours in the cold, with occasional shaking, to disperse the thick agarose--NCS mixture. The procedure results in virtually quantitative release of DNA into the scintillation cocktail, although the agarose does not dissolve completely.

\section{Results}

\section{(a) Restriction enzyme analysis of defective particle $D N A$}

Agarose gel electrophoresis of normal P22 DNA digested with the restriction endonuclease $E c o$ RI resolves eight bands (Helling et al., 1974; Jackson et al., 1978a,b). These bands can be detected by fluorescent staining with ethidium bromide (Fig. 2) or by the use of radioactive label (Fig. 3). The pattern of bands is unusual in two respects. First, the fragment seen as band $\mathrm{D}$ is present in less than molar equivalent amount. Second, material in the slowest hand is heterogeneous, migrating as a sharp zone, band $A$, with a leading shoulder containing fragments of slightly smaller molecular weight. On prolonged electrophoresis, the leading shoulder can be resolved into two minor peaks. Jackson et al. (1978a) established the physical relationship of the fragmonts, which is diagrammed on both the circular vegetative map and lincar prophage map in Figure 4. Jackson et al. $(1978 b)$ showed that the peculiarities of the restriction fragment pattern could be rationalized in terms of the sequential encapsulation model for P22 maturation described in the Introduction (Tye et al., 1974). They established that the encapsulation origin apparently lies within fragment $A$, and sequential packaging of DNA headfuls proceeds down a concatemer in a unique direction, counterclockwise on the vegetative map (Fig. 4; Jackson et al., 1978b). How the model accounts for the anomalous restriction fragments can be illustrated by considering the first of a series of molecules sequentially cleaved from a concatemer. The first molecule would vield the following fragments when digested with the EcoRI nuclease (Jackson et al, 1978b).

(1) The "proximal" fragment, derived from one end of fragment A, consists of that segment of DNA lying between the encapsulation origin and EcoRI recognition 


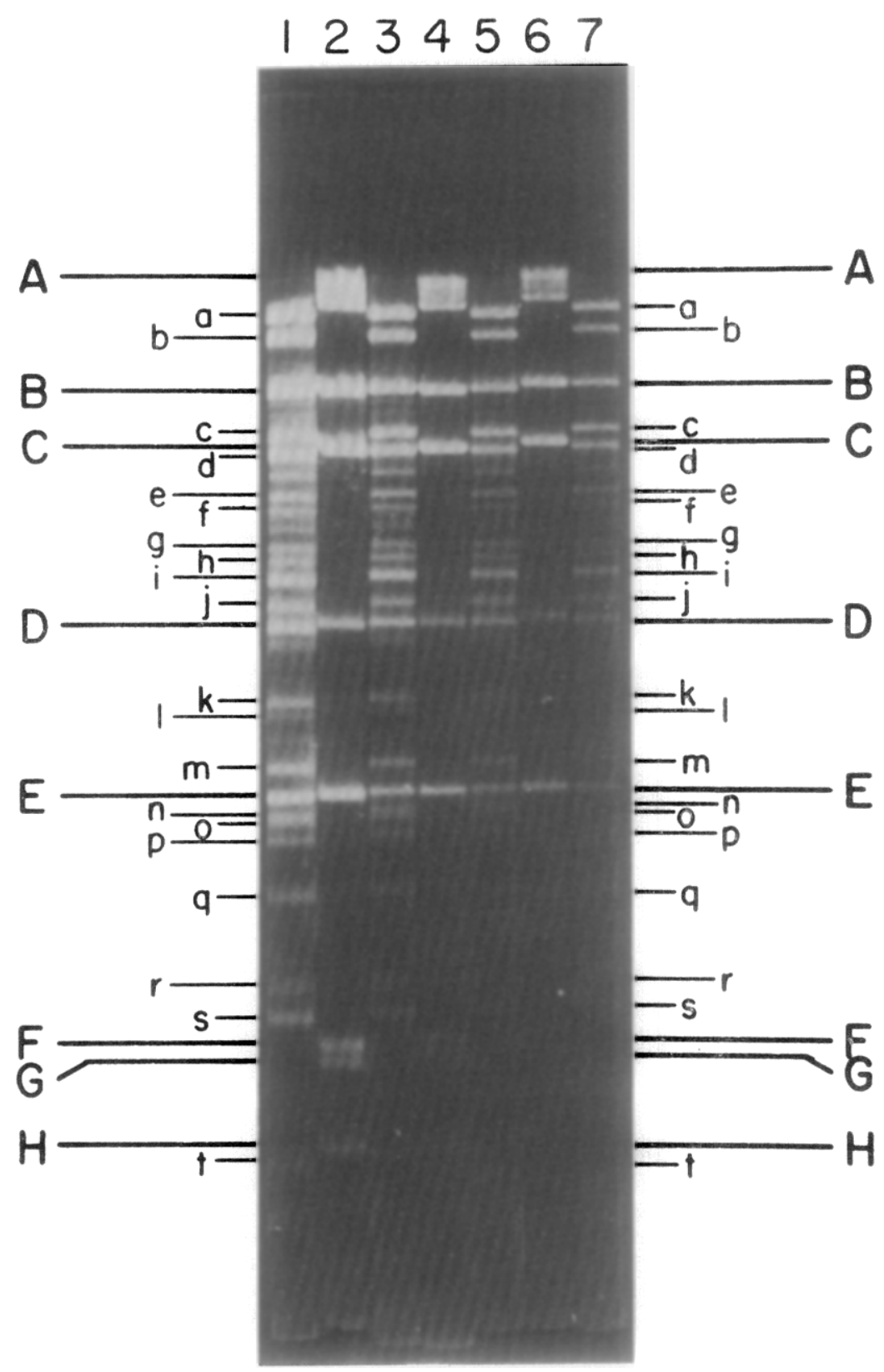

Fra. 2. Fragments of EcoRI-digested DNA resolved by electrophoresis in agarose gels and visualized by staining with ethidium bromide. Gels 1, 3, 5 and 7 contain DNA from defective particles $(3 \cdot 5,1 \cdot 8,0 \cdot 88$ and $0.44 \mu \mathrm{g}$, respectively); gels 2,4 and 6 contain DNA from normal phage $(2 \cdot 1,1 \cdot 1$ and $0.53 \mu \mathrm{g}$, respectively). Electrophoresis was for $13 \mathrm{~h}$ at $25 \mathrm{~V}$. Conditions for digestion, electrophoresis and staining are given in Materials and Methods. The bands are designated as in Table 1. 


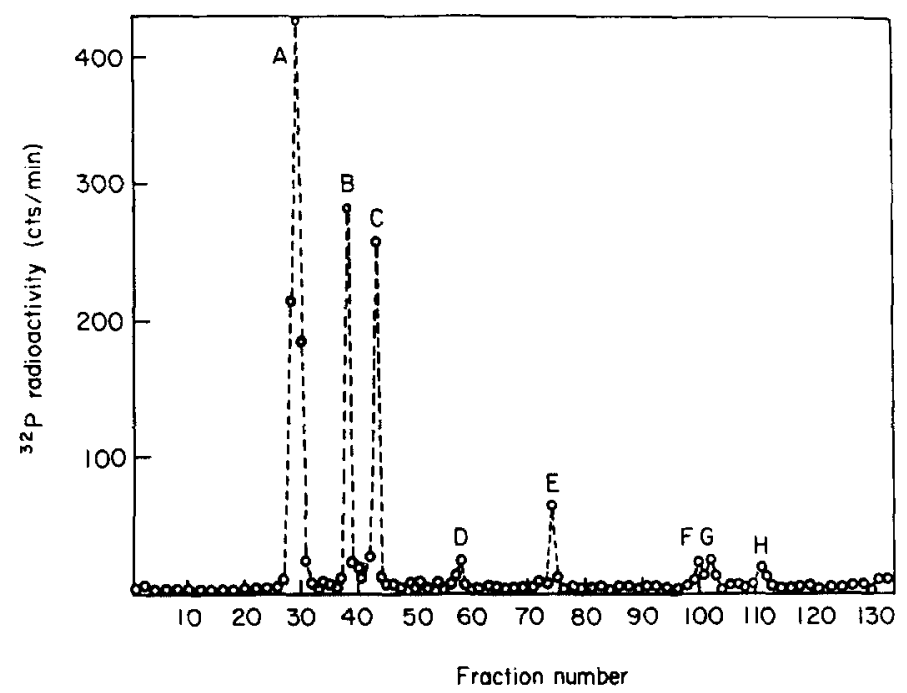

FIa. 3. Fragments of ${ }^{32} \mathrm{P}$-labeled normal P22 DNA digested with $E$ coRI and resolved by agarose gel electrophoresis. The gel was sliced, digested and counted as described in Materials and Methods. Electrophoresis was for $5.5 \mathrm{~h}$ at $60 \mathrm{~V}$. This Fig. should be compared with Fig. 2.
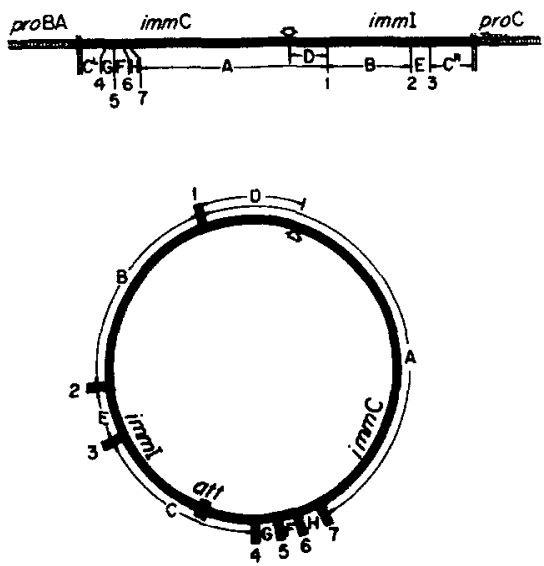

FIg. 4. Restriction map of P22. The 7 EcoRI cleavage sites, designated by numerals, are shown on both the linear prophage map and the circular vegetative map. The orientations of the 8 restriction fragments seen in agarose gels are indicated by letters. The large arrows show the position of the encapsulation origin. Sequential encapsulation proceeds rightward from this point on the prophage map, and in the counterclockwise direction on the vegetative map. This Figure is based on the results reported by Jackson et al. $(1978 a, b)$. The placernent of the immC and immI regions is approximate, and is shown only to indicate the orientation of the physical map with respect to the genetic map.

site 1. This piece of DNA is seen in agarose gels as band D. Fragment D is not a "true" restriction fragment in the sense that it has an $E c o R I$ recognition sequence at only one of its ends.

(2) The internal portion of this first headful is digested to yield, in order, fragments $\mathrm{B}, \mathrm{E}, \mathrm{C}, \mathrm{G}, \mathrm{F}$ and $\mathrm{H}$.

(3) The "distal" end of the molecule is recovered as a large piece of DNA derived from fragment A, extending from $E c o R I$ site 7 to a point one terminal redundancy 
beyond the encapsulation origin. (The terminal redundancy is about $3 \%$ of the length of the mature molecule, or about $1 / 3$ the distance between the encapsulation origin and $E c o R I$ site 1.) This fragment appears in gels as the faster of the minor bands in the leading shoulder of band $A$.

The molar deficiency of fragment $D$ arises because it is obtained only from the first headful of a series; only this molecule will possess an end at the encapsulation origin. In other words, fragment $D$ owes its existence as a discrete length of DNA to the initiation of sequential maturation at a specific site (Jackson et al., 1978b).

When DNA from defective particles obtained by induction of a P22 int- lysogen is digested with $E c o$ RI and analyzed by agarose gel electrophoresis, a more complex pattern of bands is seen. Figure 2 shows this pattern as visualized by ethidium bromide fluorescence. The results of a direct comparison of defective particle bands $\left({ }^{32} \mathrm{P}\right)$ with normal $\mathrm{P} 22$ bands $\left({ }^{3} \mathrm{H}\right)$ are plotted in Figure 5. The correspondence between the two methods of band visualization, by fluorescence and by radiolabel, is very good. All defective particle bands revealed by ethidium bromide are present

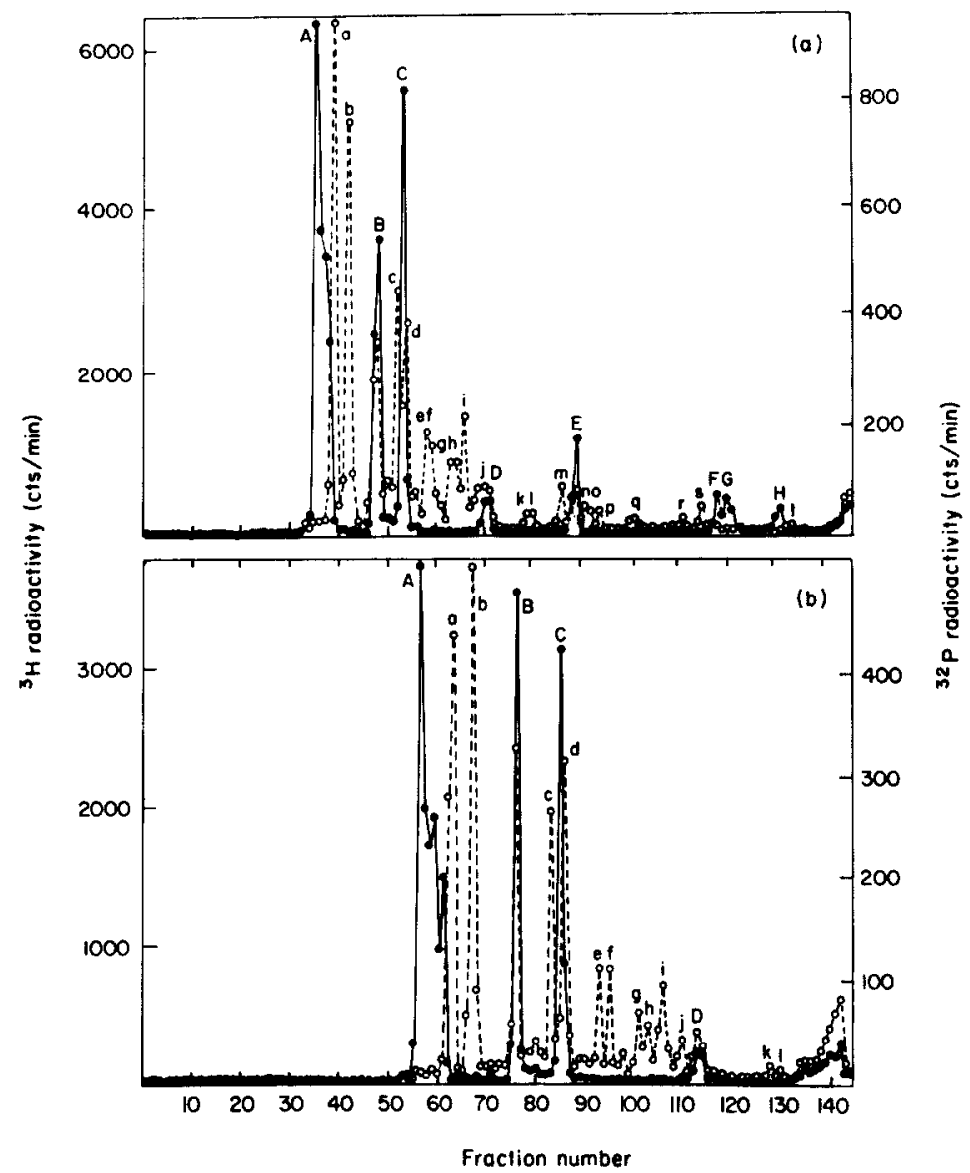

Fia. 5. Agaroise gel electrophoresis of a mixture of ${ }^{32} \mathrm{P}$-labeled defective particle DNA and ${ }^{3} \mathrm{H}$ labeled normal P22 DNA digested with EcoRI. Conditions and techniques are given in Materials and Methods. Electrophoresis was carried out at $60 \mathrm{~V}$ for $5.5 \mathrm{~h}$ (a) or for $9 \mathrm{~h}$ (b). This pattern should be tompared with the pattern revealed by ethidium bromide staining (Fig. 2). - - ${ }^{3} \mathrm{H}$ radioactivity; -- $\mathrm{O}--\mathrm{O}--$, ${ }^{32} \mathrm{P}$ radioactivity. 
as peaks of ${ }^{32} \mathrm{P}$ radioactivity in Figure 5. This indicates that all regions of the prophage and bacterial chromosome that are packaged into defective particles are replicated as well. The normal P22 bands and the major defective particle bands are enumerated in Table 1. Bands obtained from defective particle DNA but not from normal P22 DNA are designated by lower case letters in order of decreasing molecular weight. Some of the defective particle bands may well consist of two or more unresolved fragments having similar molecular weights. Further, the presence of minor fragments may be masked by stronger bands.

There is a linear relation between the logarithm of the molecular weight of a DNA molecule and its mobility during agarose gel electrophoresis (Helling et al., 1974). This relation was used to estimate the molecular weights of the defective particle fragments, using normal P22 bands as calibration standards (Fig. 6). The molecular weights of two of the defective particle bands, $a$ and $b$, fall above the range for which the linear relation holds; the sizes assigned to these two fragments are thus only very approximate.

The major differences between normal P22 DNA and defective particle DNA are as follows (Figs 2 and $5(\mathrm{a})$ and (b)).

TABLE 1

Eco $R I$ restriction fragments

\begin{tabular}{|c|c|c|}
\hline Band & $\begin{array}{l}\text { Molecular weight } \\
\left(\times 10^{-6}\right)\end{array}$ & $\begin{array}{l}\text { Relative } \\
\text { mobility }\end{array}$ \\
\hline$A^{*}$ & 13.0 & 0.57 \\
\hline $\mathrm{a}$ & 10.5 & $0 \cdot 66$ \\
\hline b & $8 \cdot 4$ & 0.73 \\
\hline B & $6 \cdot 1$ & 0.86 \\
\hline c & $5 \cdot 0$ & 0.97 \\
\hline $\mathrm{C}^{*}$ & $4 \cdot 8$ & 1.00 \\
\hline d & $4 \cdot 8$ & $1 \cdot 01$ \\
\hline e & $4 \cdot 0$ & 1.12 \\
\hline f & $3 \cdot 8$ & $1 \cdot 16$ \\
\hline $\mathrm{g}$ & $3 \cdot 4$ & $1 \cdot 26$ \\
\hline h & $3 \cdot 1$ & $1 \cdot 31$ \\
\hline i & $3 \cdot 0$ & $1 \cdot 35$ \\
\hline $\mathrm{j}$ & 2.8 & 1.40 \\
\hline D & $2 \cdot 7$ & 1.46 \\
\hline $\mathrm{k}$ & $2 \cdot 1$ & 1.67 \\
\hline 1 & $2 \cdot 0$ & 1.71 \\
\hline $\mathbf{m}$ & $1 \cdot 7$ & $1 \cdot 84$ \\
\hline $\mathbf{E}$ & 1.6 & 1.92 \\
\hline $\mathrm{n}$ & 1.5 & 1.96 \\
\hline$a$ & 1.5 & 1.98 \\
\hline $\mathrm{p}$ & $1 \cdot 4$ & 2.04 \\
\hline$q$ & 1.2 & $2 \cdot 20$ \\
\hline r & 0.92 & $2 \cdot 42$ \\
\hline $\mathrm{s}$ & 0.84 & 2.51 \\
\hline $\mathrm{F}^{*}$ & 0.75 & 2.59 \\
\hline$G^{*}$ & 0.72 & $2 \cdot 64$ \\
\hline $\mathrm{H}^{*}$ & 0.56 & $2 \cdot 86$ \\
\hline $\mathrm{t}$ & 0.55 & $2 \cdot 90$ \\
\hline
\end{tabular}

Electrophoretic mobilities are relative to band C. Molecular weights of defective particle fragments are obtained from the relationship of Fig. 6. Molecular weights of wildutype P22 $E c o R I$ fragments are those determined by Jackson et al. (1978a). Those fragments inadicated by an asterisk are not obtained from defective-particle DNA. 


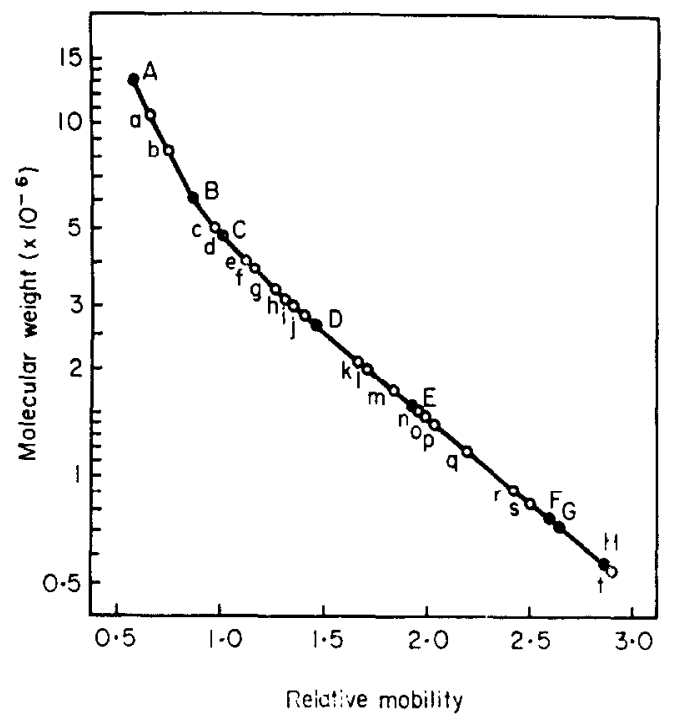

FIG. 6. Electrophoretic mobility versus molecular weight relationship used to assign molecular weights to the defective particle DNA fragments listed in Table 1. The molecular weights of the 8 normal P22 DNA fragments as determined by Jackson et al. (1978a) were used to calibrate the relationship. Mobilities were determined by measurements taken from the photograph of Fig. 2.

(1) Of the eight normal P22 bands, five, A, C, F, G and H, are not obtained when defective particle DNA is digested with EcokI. The other three fragments, D, B and $\mathrm{E}$, apparently are present, although it is theoretically possible that one or more of the three is not a normal P22 fragment but rather a new fragment of very similar molecular weight. Genetic results presented in the following sections make this possibility appear unlikely.

(2) The characteristic molar deficiency of fragment $\mathrm{D}$ in digests of normal P22 DNA is not apparent in the case of defective particle DNA, as evidenced by the relative increase in staining intensity of band $D$ from digests of defective particle DNA (Fig. 2). A similar and more quantitative conclusion may be reached by comparing the radioactivity in bands $B$ and $D$ of Figure $5(b)$. In the case of the defective particle label $\left({ }^{32} \mathrm{P}\right)$, the radioactivity in the peaks corresponding to fragments $\mathrm{B}$ and $\mathrm{D}$ is approximately $350 \mathrm{cts} / \mathrm{min}$ and $120 \mathrm{cts} / \mathrm{min}$, respectively, a proportion of 3 to 1 . In contrast, the amounts of radioactivity associated with fragments $B$ and $D$ from the normal P22 DNA marker $\left({ }^{3} \mathrm{H}\right)$ are $4200 \mathrm{cts} / \mathrm{min}$ and $450 \mathrm{cts} / \mathrm{min}$, respectively, a ratio of about 9 to 1 . Thus, it is clear that fragment $D$ is far less deficient, relative to fragment $B$, in defective particle DNA. The molecular weights of fragments $B$ and $\mathrm{D}$ are $6 \cdot 10 \times 10^{6}$ and $2 \cdot 65 \times 10^{6}$, respectively. On this basis, if these two fragments were obtained in molar equivalent amount from defective particle DNA, there should be 2.3 times as much ${ }^{32} \mathrm{P}$ label in band $\mathrm{B}$ of Figure $5(\mathrm{~b})$ as in band $\mathrm{D}$. The observed ratio is 3 . Given the low levels of ${ }^{32} \mathrm{P}$ involved in this calculation, and the inherent lack of precision in estimating the radioactivity in the peaks, these results are not inconsistent with the notion that fragments $\mathbf{B}$ and $\mathbf{D}$ are present in molar equivalent quantity in digests of defective particle DNA.

(3) A number of restriction fragments not seen in normal P22 digests are obtained from defective particle DNA (Table 1). Presumably, all these fragments contain bacterial DNA sequences. 
The DNA carried by defective particles exhibits the properties expected if it were formed by cleavage of headful lengths, beginning with the integrated prophage and proceeding rightward into the bacterial chromosome (Fig. 4). The three P22 restriction fragments that can be obtained from this DNA (fragments D, B, and E) are contiguous and lie on one side, the right-hand side, of the prophage map, indicating that the normal polarity of encapsulation is maintained. The fact that one of these three fragments is fragment $D$ confirms that the normal initiation specificity is also preserved. The first-matured headful of DNA presumably carries, in addition to fragments D, B and $\mathrm{E}$, the portion of the prophage lying between EcoRI site 3 and the attachment site (region $\mathrm{C}^{\mathrm{R}}$ in Fig. 4), as well as the pro $\mathrm{C}$ gene and sufficient additional bacterial DNA to constitute a molecule of proper length.

The molecular weights assigned to the major bands of defective particle DNA, listed in Table 1 , total about $70 \times 10^{6}$. This value for the amount of DNA carried in a population of particles is a minimum estimate, since some of the bands may consist of two or more unresolved fragments. The sum, $70 \times 10^{6}$, can be used to arrive at an estimate of the amount of prophage and bacterial DNA that is encapsulated with high frequency. Since a headful of P22 DNA is about $M_{\mathrm{r}}=28 \times 10^{6}$ (Rhoades et al., 1968), it can be estimated that sequential encapsulation usually proceeds into bacterial DNA no further than the third or perhaps fourth headful. However, the possibility that maturation may occasionally proceed much further into the host chromosome is not excluded.

\section{(b) Marker rescue experiments}

Analysis of the phage gene content of the defective particles confirms and extends the physical characterization of their DNA. Strain 18 cells $\left(s u^{-}\right)$were infected with defective particles and amber phage in the manner described in Materials and Methods and in the legend to Table 2. The infected cells were plated on strain 18 indicator. Most of the plaques reflect the rescue of an $\mathrm{am}^{+}$allele from the DNA molecule of a defective particle. However, a few of the infective centers can be attributed to the presence of $\mathrm{am}^{+}$revertants among the tester phage, and to contaminating plaqueformers in the preparation of defective particles. The data presented in column 4 of Table 2 have been corrected for these two sources of error. The amber markers examined in this experiment fall into two classes: those whose wild-type alleles are rescuable from defective particles with high efficiency, and those which exhibit relatively low rescue frequencies. The highly rescuable markers are those that lie within and to the right of gene 2 on the prophage map (Fig. 1). Mutations in the other side of the prophage map, within gene 3 and to the left, can be rescued with an approximately tenfold lower efficiency, but still somewhat above background.

These data suggest that defective particles carry a block of phage genes corresponding to the right side of the prophage, a result which is consistent with those of the previous section. The significance of the fact that markers mapping in the left half of the prophage can be resoued, albeit to a lower extent, is obscure. It suggests that there may be a minority class of defective particles which is not revealed by physical analysis, and which is not accounted for by the model.

\section{(c) Efficiency of plating on deletion lysogens}

The gene content of the defective particles can be inferred from another genetio property, their plating behavior on a series of lysogens carrying partially deleted prophage. The rationale for the analysis hinges on the supposition that defective 
TABLE 2

Marker rescue experiment

\begin{tabular}{|c|c|c|c|}
\hline \multirow[b]{2}{*}{$\begin{array}{l}\text { Amber } \\
\text { allele }\end{array}$} & \multicolumn{2}{|c|}{ Plaques observed on } & \multirow[b]{2}{*}{$\begin{array}{l}\text { "Rescue } \\
\text { plaques" } \dagger\end{array}$} \\
\hline & $\begin{array}{l}\text { Single } \\
\text { infection }\end{array}$ & $\begin{array}{c}\text { Mixed } \\
\text { infection }\end{array}$ & \\
\hline 18-amH100 & 1 & 31 & 15 \\
\hline $12 \cdot a m \mathrm{H} 145$ & 0 & 40 & 25 \\
\hline $23-a m H 79$ & 11 & 53 & 27 \\
\hline $19-a m \mathrm{~N} 111$ & 3 & 56 & 38 \\
\hline $13-a m \mathrm{H} 10 \mathrm{l}$ & 15 & 36 & 6 \\
\hline $3-a m \mathrm{~N} 102$ & 27 & 89 & 47 \\
\hline 3-amN6 & 9 & 45 & 21 \\
\hline $3-u g \mathrm{H} 5$ & 59 & 100 & 26 \\
\hline 3-amH307 & 84 & 139 & 49 \\
\hline 3-amH309 & 11 & 57 & 30 \\
\hline 3-amH317 & 19 & 42 & 8 \\
\hline $3-a m \mathrm{H} 314$ & 25 & 57 & 17 \\
\hline 2-amN16 & 5 & 340 & 320 \\
\hline 2-am $\mathrm{H} 200$ & 12 & 379 & 359 \\
\hline $2 \cdot a m H 320$ & 0 & 199 & 184 \\
\hline 2 -amH303 & 0 & 214 & 199 \\
\hline $1-a m \mathrm{~N} 10$ & 6 & 345 & 324 \\
\hline 8-amH208 & 2 & 280 & 263 \\
\hline 5. $a m \mathrm{~N} 30$ & 14 & 235 & 206 \\
\hline 10-am N33 & 1 & 525 & 509 \\
\hline $20 \cdot a m \mathrm{~N} 7$ & 5 & 227 & 207 \\
\hline $25-a m \mathrm{~N} 121$ & 6 & 160 & 139 \\
\hline $\begin{array}{l}\text { Defective } \\
\text { particles }\end{array}$ & 15 & $\ldots$ & $\ldots$ \\
\hline
\end{tabular}

T This value is the number of plaques obtained on mixed infection, minus the numbers seen on single infections with the amber phage and with defective particles. Each plate contained $10^{6}$ infected cells. The multiplicities of infection were 0.1 for defective particles and 5 for amber phage. The map order of the mutations in genes 2 and 3 is not known.

phage particles containing an incomplete genome will occasionally be able to form a plaque on a deletion lysogen if the prophage includes the portion of the genome that is lacking in the DNA of the defective particles. In other words, two incomplete but overlapping genomes, one provided by a super-infecting defective particle and the other by the resident prophage, can interact to reform an intact phage genome. Due to contamination with plaque-formers, preparations of defective particles plate with a certain low efficiency even on a non-lysogen. So, from an experimental standpoint, an increase in the plaque-forming unit titer of a defective particle preparation when plated on a deletion lysogen, relative to that seen on a non-lysogenic indicator, is taken to mean that the prophage carries all genes missing in the defective particles. The obverse is also assumed: failure to plate with enhanced efficiency on a deletion lysogen indicates that the prophage is deleted for a portion of the genome lacking in the defective particles.

The deletion lysogens used were isolated and characterized by Chan \& Botstein (1972). The prophage in these strains carries an insertion, between gene 9 and the right attachment site, that confers tetracycline resistance (Fig. 1). The deleted region begins just to the left of the tet ${ }^{\mathrm{R}}$ insertion, extends through gene 9 , the $\mathrm{imml}$ 


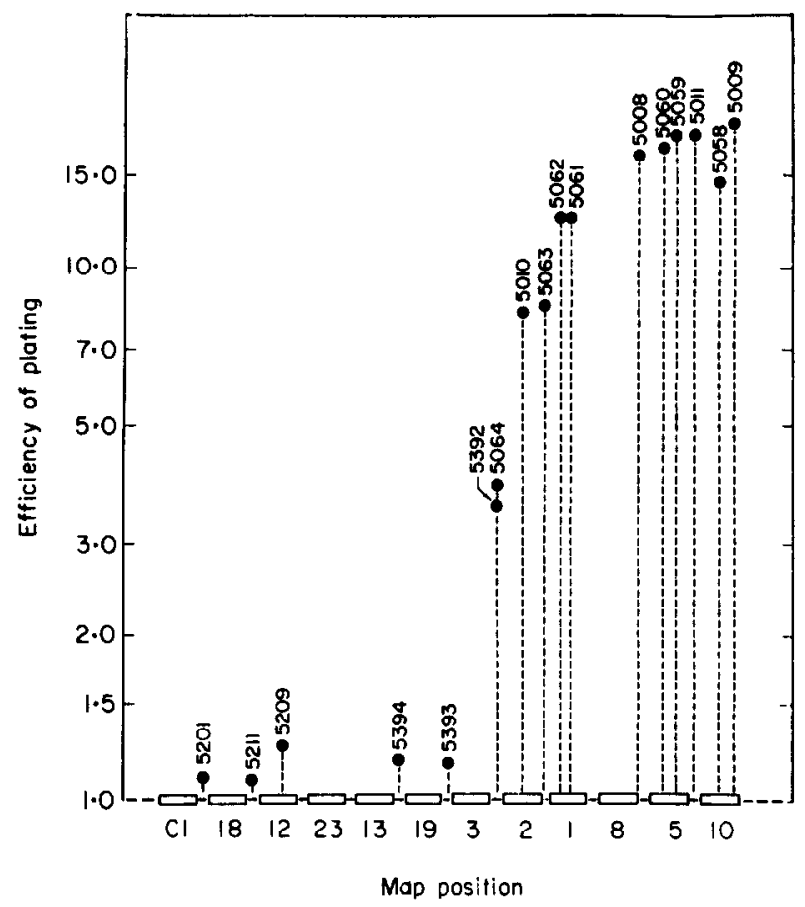

FIa. 7. Efficioney of plating of defective particles on $\mathrm{P} 22$ deletion lysogens. Plating efficiencies are relative to that observed with a non-lysogenic indicator. The efficiencies are plotted versus the deletion endpoint of each of the lysogens (see Fig. 1).

region, and into the central portion of the prophage. A preparation of defective particles was assayed on this series of deletion lysogens, and the results are diagrammed in Figure 7. Here the relative number of plaques observed on each of the strains is plotted against the map position of the deletion endpoint. An increased efficiency of plating is seen on strains whose deletion endpoint falls to the right of gene 3. All the lysogens in which material to the left of gene 2 has been deleted give a plating efficiency comparable to that obtained with a non-lysogen. These results confirm the conclusion reached previously: the defective particles carry genes derived from the right side of the prophage, starting at a point near gene 3 .

\section{(d) Replication in excision-defective lysogens}

Our results suggest that the defective particles carry DNA which is derived principally from a limited region of the prophage and bacterial chromosome, a region perhaps the length of three or four contiguous headfuls. Clearly, the packaged region must undergo a number of rounds of replication prior to encapsulation, since several hundred particles are released from each induced cell (Smith, 1968). Additional evidence that DNA is replicated before being incorporated into defective particles is the observation, made in a preceding section, that radioactive precursor administered after induction appears in all the EcoRI restriction fragments of defective particle DNA.

These considerations raise the question of whether the entire prophage is replicated or whether replication is limited to the region which is destined to be encapsulated. 
To investigate this matter, lysogen 1032 was thermally induced and labeled with $\left[{ }^{3} \mathrm{H}\right]$ thymidine as described in Materials and Methods. The prophage in this strain carries an int mutation, a $c 2$-ts allele to confer thermal inducibility, and an amber mutation in gene 19 to forestall spontaneous lysis. As a control, the non-lysogenic parent, strain 18, was mock-induced and labeled in parallel. DNA from the two cultures was purified, digested with $E c o$ RI and analyzed by gel electrophoresis. The results obtained are plotted in Figure 8 (a) and (b) and in the upper six panels of Figure 9. The gels of Figure 8 show the complete distribution of restriction fragments; in Figure 9 are plotted portions of other gels which were run for different times to allow better resolution of fragments of certain size classes.

The pattern of fragments obtained from the induced lysogen and mock-induced non-lysogen are very different. The labeled DNA from the non-lysogen is digested by $E c o$ RI to yield a large number of fragments which are, in general, not resolved. In contrast, the DNA from the induced lysogen yields a smaller number of bands, most of which can be resolved and some of which comigrate with the marker bands of normal P22 DNA. This confirms that bacterial DNA synthesis is strongly inhibited on induction (Botstein, 1968), and that most of the labeled DNA obtained from the induced lysogen has been replicated under control of the prophage. A rough idea of the magnitude of the reduction of bacterial DNA synthesis may be had by comparing the amount of material in the heterogeneous zone migrating more slowly than $\mathrm{P} 22$ fragment $A$ (fractions 70 to 75) in Figure 9(a) with the same region in Figure $9(\mathrm{~b})$.

The five EcoRI fragments that together comprise the interior of the prophage are recovered as labeled species from the induced lysogen. Peaks of ${ }^{3} \mathrm{H}$ corresponding to P22 fragments $\mathrm{A}$ and $\mathrm{B}$ are evident in Figure $9(\mathrm{~b})$; peaks in the positions of fragments E, F, G, and $\mathrm{H}$ can be seen in Figure $9(\mathrm{~h})$. In addition, a peak of ${ }^{3} \mathrm{H}$-labeled fragment D may be seen in Figure 9(e). As discussed above, the presence of fragment $\mathrm{D}$ indicates that the normal site and directional specificities of P22 encapsulation are maintained. At the time that these lysates were prepared ( $45 \mathrm{~min}$ after induction) all the available DNA had apparently not been encapsulated. If this had been the case, no full-length fragment $A$ should have been seen. In fact, a substantial amount of fragment A was observed (Fig. 9(b)). Fragment C is not recovered as a labeled species. This provides direct confirmation that excision does not take place and that replication of phage DNA occurs in situ, while integrated within the bacterial chromosome.

Two new bands, indicated by arrows in Figure 9(b), were obtained from the induced lysogen DNA. These bands are characteristic neither of defective particle DNA nor of normal P22 DNA. Since prophage DNA to the left of the encapsulation origin (fragments $\mathrm{G}, \mathrm{F}, \mathrm{H}$ and $\mathrm{A}$ ) is replicated, one would expect prophage and bacterial DNA to the left of EcoRI recognition site 4 be replicated as well (Fig. 4). The two new bands might thus correspond to material to the left of fragment $G$. However, since fragment $\mathrm{D}$, the portion of fragment A lying to the right of the encapsulation origin, is found, one might expect the "complement" of fragment $D$ to be present as well. Such a fragment, consisting of the region of fragment A lying to the left of the encapsulation origin, would have a molecular weight of about $10 \times 10^{6}$, the size of the larger of the two new bands. That this band is not part of fragment A is suggested by data given in the next section.

These observations suggest that induction of an excision-defective lysogen leads to replication of the entire length of the prophage, apparently while still integrated within the host chromosome, and despite the fact that only a portion of the prophage 


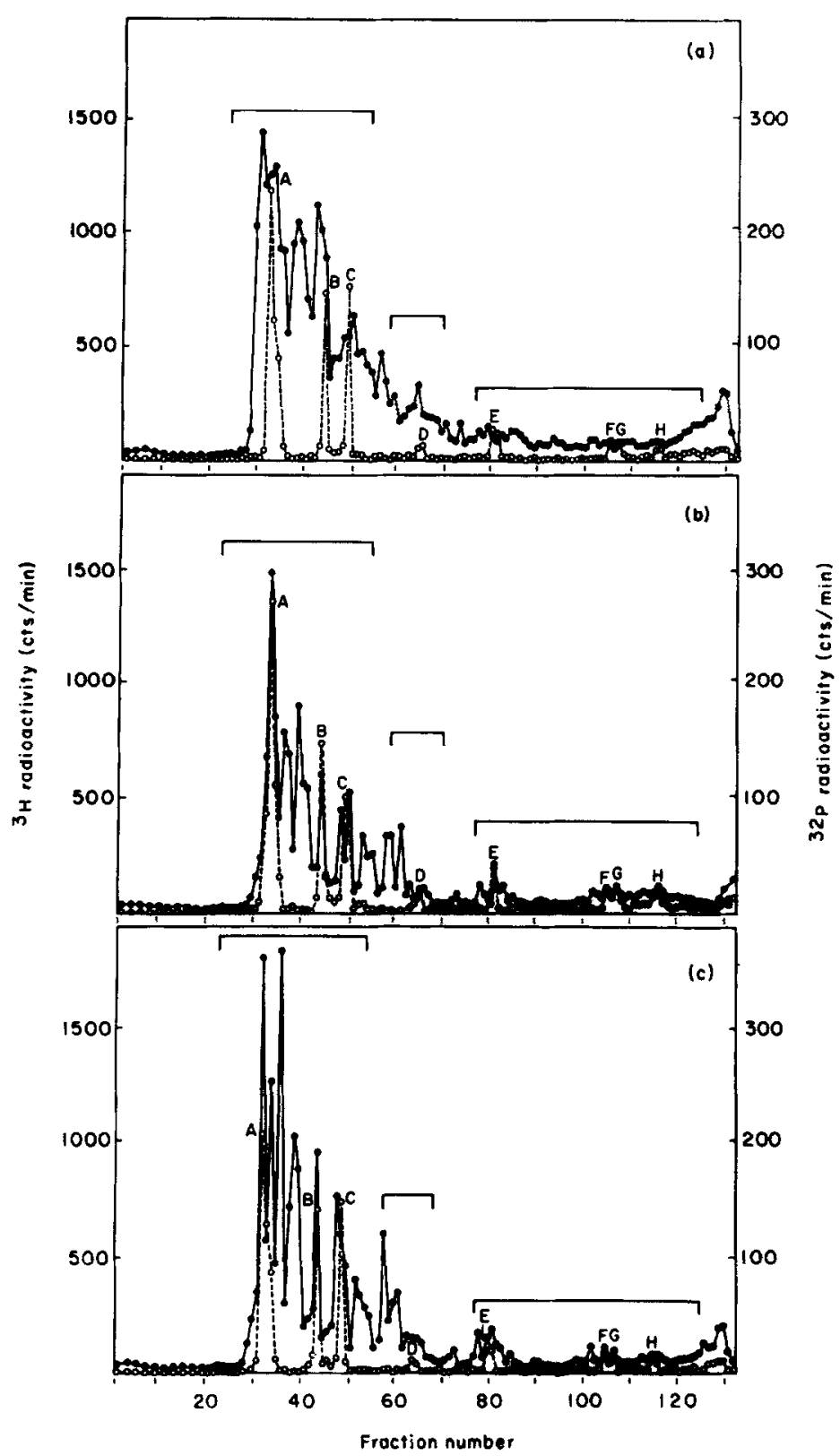

Fra. 8. Agarose gel electrophoresis of EcoRI digests of intracellular DNA labeled with [ $\left.{ }^{3} \mathrm{H}\right]$ thymidine after thermal induction of strains 18 (a), 1032 (18 (int3 c2-ts29 19-amN111)) (b), 1033 (18 (int3 c2-ts29 19-amN111 1-ts1-1))(c). As a marker, ${ }^{32}$ P-labeled normal P22 DNA was included in the EcoRI digestion reaction. Letters denote the 8 fragments obtained from this marker DNA. Electrophoresis was for $5.5 \mathrm{~h}$ at $60 \mathrm{~V}$. Conditions and techniques are described in Results and in Materials and Methods. The brackets indicate the fragment size classes which are resolved more clearly in the individual panels of Fig. 9. - - - - - ${ }^{3} \mathrm{H}$ radioactivity; - $\mathrm{O}_{--} \mathrm{O}_{--},{ }^{32} \mathrm{P}$ radioactivity. 

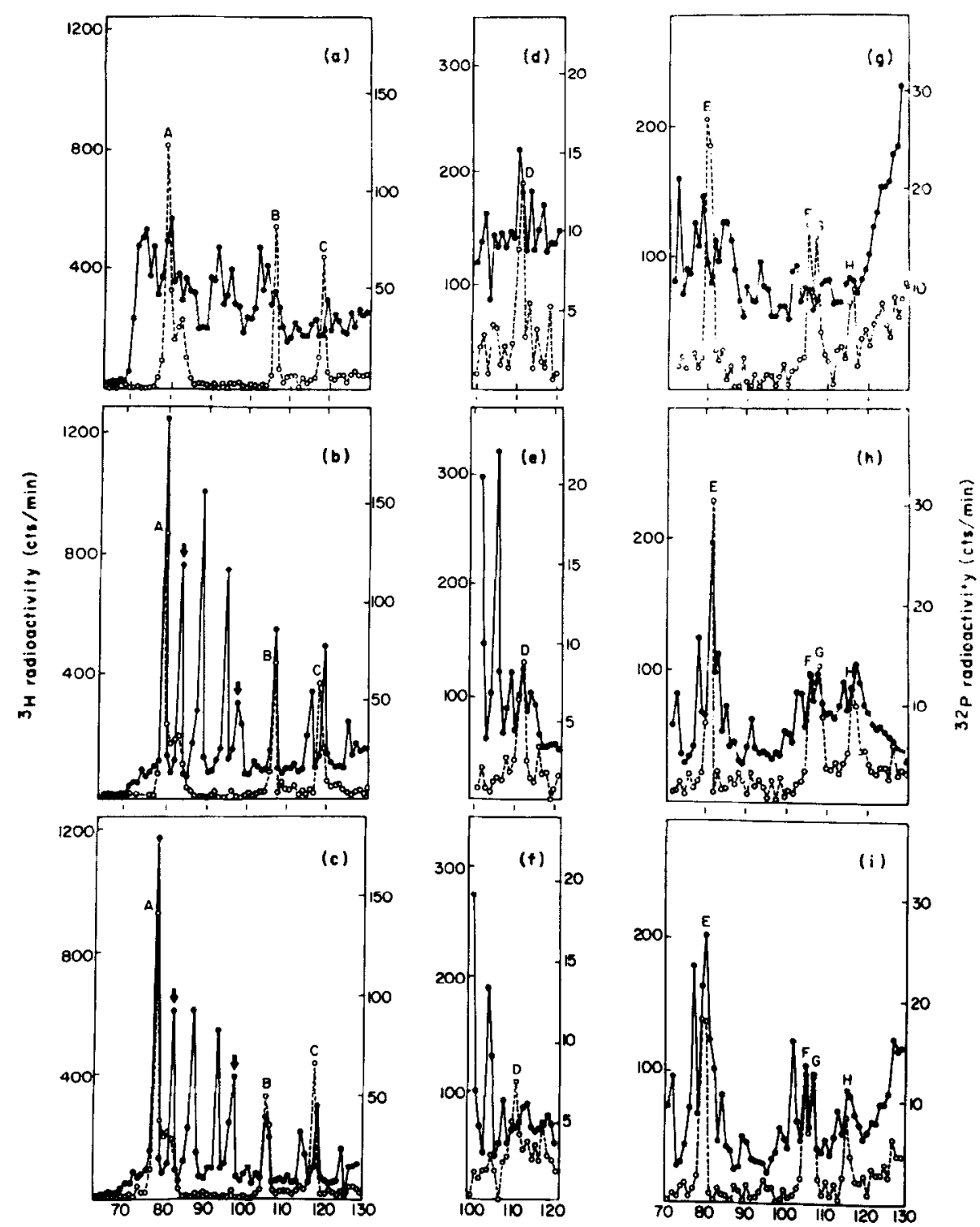

Froction number

FIG. 9. Portions of gels showing particular size classes of $E$ coRI fragments of intracellular DNA labeled with $\left[{ }^{3} \mathrm{H}\right]$ thymidine after induction of lysogens. (a) to (i) correspond to the brackets of Fig. 8. The gels (a), (d) and (g) show the patterns obtained with DNA from strain 18 (Fig. 8(a)); (b), (e) and (h), the DNA from induced strain 1032 (Fig. 8 (b)); and (c), (f) and (i), the DNA from induced strain 1033 (Fig. 8 (c)). Electrophoresis was carried out at $60 \mathrm{~V}$. The gels of (a) to (c) were run for $13 \mathrm{~h}$; the gels of (d) to (f) for $9 \mathrm{~h}$; and the gels of (g) to (i) for $5.5 \mathrm{~h}$. The latter 3 panels are the right-hand portions of the gel patterns of Fig. 8, plotted on a different scale. The arrows in (b) and (c) show 2 fragments that are not obtained from defective particle DNA (see text). ${ }^{3} \mathrm{H}$ radioactivity; $--O \quad O \quad,{ }^{32} \mathrm{P}$ radioactivity. 
will ultimately be packaged. Replication apparently can occur without disruption of the linear integrity of the prophage. Particularly significant in this respect is the fact that fragment $A$ is replicated as an intact length of DNA, even though the encapsulation origin lies within it.

\section{(e) The basis of the encapsulation origin specificity}

Two mechanisms for the site-specificity of the initiation of sequential DNA encapsulation have been proposed (Tye et al., 1974; Tye, 1976). One general idea is that packaging begins at a unique site as a reflection of the mechanism of DNA replication. For example, the site might correspond to a unique free end of a concatemer produced by rolling circle replication. In this case, the encapsulation origin would be the same as the replication origin. The alternative notion is that the packaging initiation specificity resides instead in the morphogenesis pathway, some component of which would recognize the origin as an internal site on the DNA molecule to be encapsulated, leading to an endonucleolytic cleavage at that site. The following experiment attempts to distinguish between these two possibilities.

As discussed previously, $E c o$ RI fragment D may be obtained from P22 DNA only if that DNA has been acted upon by whatever mechanism is responsible for the site-specificity of DNA encapsulation. In other words, EcoRI fragment D may serve as an indirect assay for the operation of the specificity-determining mechanism (Jackson et al., 1978b). In the last section we demonstrated that induction of an excision-defective lysogen results in the replication of the entire prophage and in the manifestation of the normal encapsulation initiation specificity. In an extension of this type of experiment, another $i n t^{-}$lysogen, strain 1033, was induced, labeled and its DNA extracted and analyzed by $E$ coRI digestion and gel electrophoresis. Strain 1033 is isogenic with strain 1032, except that it carries a temperature-sensitive mutation in gene 1 , in addition to the $i n t, c 2-t s$ and gene 19 mutations. Botstein et al. (1973) have shown that gene 1 function is required during morphogenesis for head maturation and DNA encapsulation. These functions are thus expected to be blocked upon high-temperature induction of strain 1033.

The results obtained are displayed in Figure 8(c) and in Figure 9(c), (f) and (i). The pattern of restriction fragments is virtually the same as that obtained in the case of strain 1032, where particle morphogenesis was not prevented. This indicates that, as expected, the block in morphogenesis does not alter the pattern of DNA synthesis, and also provides a demonstration of the reproducibility of the experimental system.

With respect to fragment $D$, however, there does appear to be a difference in the two patterns. The small peak of ${ }^{3} \mathrm{H}$ in the position of fragment $\mathrm{D}$ obtained from strain 1032 (Fig. 9(e)) is absent in the case of strain 1033 (Fig. 9(f)). The deficiency in fragment $D$ in the latter instance is a slight effect, amounting to a difference of only a few counts per minute in two fractions. We believe that the difference is real for the following reasons. With the exception of the two fractions that comprise fragment D, the distribution of ${ }^{3} \mathrm{H}$ in Figure $9(\mathrm{e})$ and $9(\mathrm{f})$ is the same. In particular, in each case there are two clear peaks migrating three and seven fractions more slowly than the peaks of ${ }^{32} \mathbf{P}$-labeled fragment $\mathrm{D}$ marker. And in both cases there is another peak migrating two to three fractions more rapidly.

The two new bands indicated by arrows in Figure 9(b) (described in section (d), above) were also obtained from the DNA of this induced lysogen (Fig. 9(c)). That 
these bands are found in the apparent absence of fragment $D$ supports the earlier suggestion that they may correspond to material to the left of fragment $G$.

The fact that a defect in particle morphogenesis can affect the recovery of fragment D without otherwise altering the pattern of DNA synthesis suggests that DNA replication per se is not responsible for the formation of a DNA molecule with a free end at the encapsulation origin. Rather, such a molecule would appear to result from endonucleolytic cleavage at the appropriate site during the process of particle assembly and DNA maturation.

\section{Discussion}

The properties of the defective particles produced by an induced excision-defective P22 lysogen can be accounted for in terms of the sequential encapsulation model for P22 DNA maturation proposed by Tye et al. (1974) and extended in the accompanying paper (Jackson et al., 1978b). As described in the Introduction, if DNA headfuls were cut from the integrated prophage and adjacent bacterial chromosome with the specificities associated with normal maturation, DNA to only one side of the encapsulation origin would be packaged. We have shown that only three of the eight EcoRI restriction fragments associated with normal P22 DNA can be obtained from defective particle DNA. These three, fragments D, B and E, lie next to one another to the right side of the prophage map. The fact that fragment $\mathrm{D}$ is obtained is of particular interest, since it indicates that both the initiation and directional specificities of normal P22 DNA maturation are maintained during the production of defective particles (Jackson et al., 1978b), and that only a precise block of prophage genes is packaged.

Analysis of the phage gene content of defective particles by two biological techniques confirmed the interpretation of the physical studies. Most of the particles carrying phage DNA apparently contain a particular segment of the genome, derived from the right side of the prophage. The left margin of this block of genes, which should correspond to the encapsulation origin, apparently lies near gene 3 , at about the midpoint of the prophage. Our ability to determine the genetic position of the encapsulation origin precisely is subject to limitations inherent in the biological methods. In the case of marker rescue experiments, the recovery of a genetic marker located close to the end of a DNA molecule (i.e. near the encapsulation origin) may be inhibited. We found that markers in gene 2 are rescued from defective particles with high frequency and markers in gene 3 are not. The simple interpretation is that the origin maps between these two genes, but the possibility that it really lies further to the left cannot be eliminated.

Conclusions based on the plating efficiencies of defective particles on deletion lysogens must also be qualified. Reconstitution of a complete phage genome requires recomlination ketween the DNA of the deleted prophage and the DNA of the defective particle. One crossover event must occur in the interval between the left end of the defective particle DNA molecule and the deletion endpoint of the prophage. Clearly, if there is no homology in this interval, that is if the encapsulation origin in the prophage is deleted, infection by a defective particle will never result in an infective center. This is the basis of the experiment. What is not clear is the extent of overlap required for plaques to appear with frequency greater than the background. That limited homology may have an effect is indicated in Figure 7 by the somewhat lower plating efficiencies of defective particles on lysogens DB5392 and DB5064. 
The potential bias involved in both of these biological mapping methods would have the same effect: in each case the encapsulation origin would appear to be to the right of its actual map position. Simply interpreted, our results place the encapsulation origin between genes 2 and 3 , although it may lie somewhat to the left, within gene 3 or perhaps between genes 19 and 3 . In the latter case, the site would be analogous to the genetic position of the ends of the mature $\lambda$ DNA molecules.

The genetics of P22 pro-3 transducing particles (Chan, 1974) allows a similar conclusion about the position of the encapsulation origin. These particles arise by induction of a $\mathrm{P} 22$ prophage into which the host proAB genes are inserted between gene 9 and the right attachment site (Jessop, 1972). Heteroduplex analysis revealed that pro-3 DNA molecules lack a terminal redundancy, apparently because the deletion-substitution of bacterial DNA results in a net insertion very close to the same length as the normal terminal redundancy, increasing the length of the pro-3 genome to approximately the same size as a P22 headful. The model for P22 DNA maturation proposed by Tye et al. (1974) predicts that encapsulation of headfuls from concatemeric pro-3 DNA will produce molecules that are permuted to a very slight extent, and whose termini lie very close to the encapsulation origin.

P22 pro-3 particles plate with an efficiency of about $10^{-2}$. This defect presumably resides in the lack or near lack of a terminal redundancy, and the consequent inability of pro-3 DNA to be circularized on infection. However, Chan (1974) showed that these particles can plate with an efficiency as high as 0.5 on certain prophage deletion lysogens (see Fig, 1): those in which the region around gene 3 is retained. On lysogens in which this region is deleted, pro-3 particles plate with the low efficiency characteristic of non-lysogenic indicators. Chan (1974) rationalized this behavior by supposing that circularization of pro-3 particle DNA could be achieved by recombination with the partially deleted prophage if the latter included the portion of the genome spanning the termini of pro-3 DNA. Thus, Chan's (1974) results confirm our conclusion that the encapsulation origin lies in the vicinity of gene 3 .

The bacterial DNA carried in the defective particles produced on induction of an excision-defective P22 lysogen is presumably derived from the proC region of the host chromosome. Although it is difficult to imagine an alternative, the only direct evidence that proC DNA is encapsulated is Smith's (1968) observation of elevated transduction of proC and pur $\mathrm{E}$ by defective particles. By summing the molecular weights of the major $E c o R I$ restriction fragments of defective particle DNA, it can be estimated that sequential encapsulation of the proC region does not proceed with high frequency beyond the third or fourth headful, although this probably does happen occasionally. The purE gene, which can be packaged, maps about nine minutes away from proC. This is about $6 \%$ of the 138-minute map (Sanderson, 1972), a distance equivalent to about six P22 headfuls.

Substantial replication of the prophage and neighboring bacterial DNA precedes the morphogenesis of defective particles. This replication is not limited to the DNA that will be packaged. All of the six $E c o R I$ fragments which derive from the interior of the prophage, G, F, H, A, B and $\mathbf{E}$, are obtained from labeled intracellular DNA, even though only $B, E$ and a portion of $A$ (fragment $D$ ) are to be found in defective particles. The absence of one of the $\mathrm{P} 22$ restriction fragments, fragment $\mathrm{C}$, provides confirmation that prophage excision does not take place. Additionally, the fact that the missing fragment is fragment $C$ confirms the finding of Jackson et al. (1978a) that the attachment site maps within fragment $C$. These observations suggest that 
prophage DNA is replicated in situ on the host chromosome as an intact linear structure. This type of replication is clearly distinct from the normal mode of phage DNA synthesis, which involves a very rapidly sedimenting replication complex not associated with the bacterial chromosome (Botstein, 1968). The simplest way to imagine how replication proceeds in situ would be by a symmetrical, bidirectional mode, initiating at a site within the prophage genome. A diagram illustrating this scheme is presented in Figure 10. By an analysis of the properties of P22- $\lambda$ hybrid phage, Hilliker (1974) has shown that the replication origin of P22 probably lies near the DNA replication genes, 12 and 18 , just to the right of the $i m m \mathrm{C}$ region. Jackson et al. $(1978 a)$ demonstrated that this region corresponds to the rightward portion of fragment $A$.

The six "interior" restriction fragments G, F, H, A, B and E are obtained from replicated intracellular DNA, whether or not the encapsulation of that DNA into particles has been permitted. However, the unusual fragment $D$ (which has an end at the encapsulation origin) can be eliminated or reduced by a mutation in gene 1 , a morphogenetic function. This indicates that DNA molecules terminating at the encapsulation origin are probably formed by a process that is associated with particle morphogenesis, presumably a site-specific cleavage, rather than with replication itself (Fig. 10). In other words, recognition of the site of encapsulation origin is a property of the morphogenesis system, rather than of the replication machinery. The specificity of the first cleavage, as well as the direction in which maturation cutting proceeds, presumably resides in the nucleotide sequence at the encapsulation origin. One unexplained aspect of maturation is the way that the first or primary cleavage can be determined by sequence, when all subsequent cleavages are determined solely on the basis of DNA length.

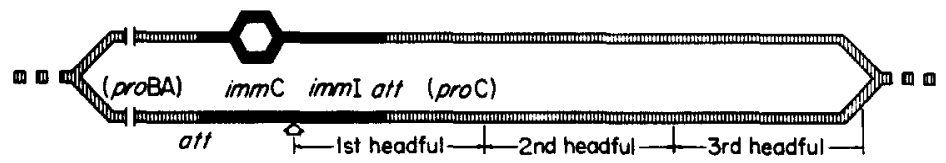

FIG. 10. A model for the replication and encapsulation of unexcised prophage DNA. Bidirectional replication is shown, beginning within the prophage and extending into the host chromosome. A second round of synthesis has initiated near the $i m m \mathrm{C}$ region. The arrow shows the position of the encapsulation origin. Defective particles are formed by the encapsulation of headful lengths of DNA which have been cleaved sequentially from the prophage and bacterial chromosomes as shown.

Generalized transducing particles (Ebel-Tsipis et al., 1972) are found in lysates of normal P22 because of occasional improper recognition and encapsulation of bacterial DNA. Any mutation that alters the sequence at the encapsulation origin, or which affects those proteins involved in the recognition of that sequence, might be expected to alter the frequency of generalized transducing particles. Schmieger (1972) has isolated mutants which affect the frequency of generalized transduction. They fall into two classes: the ht mutants, which give increased frequencies of transducing particles, and the $n t$ type, which exhibit abnormally low frequencies of transduction. Tye (1976) characterized the DNA of one of the $h t$ mutants by heteroduplex analysis, and found that the ends of these molecules were not restricted to a small sector of the map, as is true for normal P22 DNA but rather were widely scattered, apparently 
randomly. Thus, a mutation that alters the frequency of transduction can apparently also interfere with the initiation of phage DNA encapsulation at the proper site.

Genetic analyses suggest the presence in defective particle preparations of two rare types of particles whose existence is not explained by the model diagrammed in Figure 10. These are the plaque-forming particles (which are still int ${ }^{-}$), and the defective particles that seem to carry genes from the left half of the prophage. The first class may arise from cells in which excision does occur, perhaps through leakiness of the int mutation. One way to think about the second type of defective particles is to suppose that they arise by "erroneous" packaging of random segments of prophage and bacterial DNA, perhaps in a way analogous to encapsulation of bacterial DNA into transducing particles during normal P22 morphogenesis. An alternative explanation would be the encapsulation of a headful of DNA beginning at the normal origin but extending to the left, rather than in the proper rightward direction.

The induction of an excision-defective $\lambda$ monolysogen leads to the production of defective particles by a mechanism very similar to that we have just described (Sternberg \& Weisberg, 1975). The majority of the particles, called $\lambda d o c \mathrm{~L}$, contain DNA extending from the cos site rightward, including bacterial DNA from the bio side of the prophage. Much rarer is the complementary type, $\lambda d o c \mathrm{R}$, which carries prophage DNA to the left of cos and DNA from the bacterial gal region.

We are grateful to Mr Joseph Bellestri for skilled assistance. We thank Dr Ethel Jackson and her co-workers for communicating to us their unpublished EcoRI cleavage map and their characterization of the process of encapsulation of P22 DNA. Drs Don Clewell and David Friedman provided helpful discussions and criticism of the manuscript. This work was supported by Public Health Service Grant no. GMI5419 from the National Institute for General Medical Sciences. One of us (S. W.) was a National Institutes of Health predoctoral fellow supported by a training grant (no. GM00071) from the United States Public Health Service.

\section{REFERENCES}

Botstein, D. (1968). J. Mol. Biol. 34, 621-641.

Botstein, D. \& Levine, M. (1968). J. Mol. Biol. 34, 643-654.

Botstein, D. \& Matz, M. D. (1970). J. Mol. Biol. 54, 417-440.

Botstein, D., Chan, R. K. \& Waddell, C. (1972). Virology, 49, 268-282.

Botstein, D., Waddell, C. \& King, J. (1973). J. Mol. Biol. 80, 669-695.

Botstein, D., Lew, K. K., Jarvik, V. \& Swanson, C. A. Jr (1975). J. Mol. Biol. 91, 439 -462.

Bronson, M. J. \& Levine, M. (1971). J. Virol. 7, 559-568.

Chan, R. K. (1974). Ph.D. thesis, Massachusetts Institute of Technology.

Chan, R. K. \& Botstein, D. (1972). Virology, 49, 257-267.

Ebel-Tsipis, J., Botstein, D. \& Fox, M. S. (1972). J. Mol. Biol. 71, 433-448.

Enquist, L. W. \& Skalka, A. (1973). J. Mol. Biol. 75, 185-212.

Gottesman, M. \& Yarmolinsky, M. (1968). Cold Spring Harbor Symp. Quant. Biol. 33, $735-747$.

Gough, M. (1970). J. Virol. 6, 320-324.

Helling, R. B., Goodman, H. M. \& Boyer, H. W. (1974). J. Virol. 14, 1235-1244.

Hilliker, S. (1974). Ph.D. thesis, Massachusetts Institute of Technology.

Hoffman, B. \& Levine, M. (1975). J. Virol. 16, 1536-1546.

Israel, V. (1967). Virology, 33, 317-322.

Israel, J. V., Anderson, T. F., \& Levine, M. (1967). Proc. Nat. Acad. Sci., U.S.A. 57, 284-291.

Jackson, E. N., Miller, H. I. \& Adams, M. L. (1978a). . I. Mol. Biol. 118, 347-363.

Jackson, E. N., Jackson, D. A \& Deans, R. J. (1978b). J. Mol. Biol. 118, 365-388.

Jessop, A. P. (1972). Mol. Gen. Genet. 114, 214-222.

Levine, M. (1957). Virology, 3, 22-41. 
Levine, M. \& Curtiss, R. (1961). Genetics, 45, 1573-1580.

Levine, M. \& Smith, H. O. (1964). Science, 146, 1581-1582.

Levine, M., Truesdell, S., Ramakrishnan, T. \& Bronson, M. J. (1975). J. Mol. Biol. 91, 421-438.

Rhoades, M., MacHattie, L. A. \& Thomas, C. A. Jr (1968). J. Mol. Biol. 37, 21-40.

Sanderson, K. E. (1972). Bacteriol. Rev. 36, 558-586.

Schmieger, H. (1972). Mol. Gen. Genet. 119, 75-88.

Smith, H. O. (1968). Virology, 34, 203-223.

Smith, H. O. \& Levine, M. (1964). Proc. Nat. Acad. Sci., U.S.A. 52, 356363.

Smith, H. O. \& Levine, M. (1967). Virology, 31, 207-216.

Sternberg, N. \& Weisberg, R. (1975). Nature (London), 256, 97-103.

Streisinger, G., Emrich, J. \& Stahl, M. M. (1967). Proc. Nat. Acad.Sci., U.S.A. 57, 292-295.

Tye, B. K. (1976). J. Mol. Biol. 100, 421-426.

Tye, B. K., Huberman, J. A. \& Botstein, D. (1974). J. Mol. Biol. 85, 501-532.

Young, E. T. II \& Sinsheimer, R. L. (1967). J. Mol. Biol. 30, 165-200. 